\title{
PENDEFINISIAN OBJEK DAN PELENGKAP DALAM KAMUS BESAR BAHASA INDONESIA SEBAGAI PENUNJANG LITERASI
}

\author{
Dewi Puspita ${ }^{1}$ Hermina Sutami ${ }^{2}$ \\ Universitas Indonesia ${ }^{12}$ \\ dewi_puspita18@yahoo.com¹; h_sutami@yahoo.com²
}

\begin{abstract}
Abstrak
Literasi tidak dapat dipisahkan dari kemampuan berbahasa. Kemampuan berbahasa yang paling dasar adalah kemampuan untuk merangkai kata hingga menjadi ujaran yang dapat dipahami. Untuk itu, diperlukan pemahaman yang tepat mengenai unsur-unsur pembentuk kalimat dan fungsinya. Sayangnya, definisi dua fungsi unsur kalimat, yaitu objek dan pelengkap dalam KBBI masih bertumpang tindih. Definisi yang tumpang tindih itu dapat membingungkan pengguna bahasa. Makalah ini disusun untuk memperjelas perbedaan antara objek dan pelengkap serta memperbaiki kekurangtepatan definisi kedua kata ini. Dengan demikian, definisi keduanya menjadi lebih sesuai dan mudah dipahami oleh pemelajar bahasa Indonesia. Penelitian ini dilakukan dengan pendekatan fungsionalisme melalui analisis fungsi sintaktis dan semantis, serta memperhatikan prinsip-prinsip leksikografi. Analisis dilakukan pada enam kalimat yang merupakan tuturan alami. Kalimat-kalimat tersebut diambil dari korpus web bahasa Indonesia. Hasil analisis data dalam penelitian ini menunjukkan bahwa objek dan pelengkap memang berbeda. Dari perbedaan itu diperoleh batasan yang jelas dan tidak tumpang tindih.
\end{abstract}

Kata kunci: definisi, objek, pelengkap, literasi, leksikografi

\begin{abstract}
Literacy cannot be separated from language skills. The most basic language skills are the ability to compose meaningful utterances. For that purpose, a proper understanding of the sentence-forming elements and their functions is needed. Unfortunately, the definitions of the two sentence element functions, namely objects and complements, in KBBI still overlap. The overlapping definition can confuse language users. This paper aims to clarify the differences between object and complement and to correct the inaccuracies in the definition of these two words. Thus, the definition of each of the two functions becomes more appropriate and easily understood by Indonesian language learners. This research was conducted with a functionalism approach through the analysis of syntactic and semantic functions, by paying attention to lexicographic principles. The analysis was carried out on six naturally occurring sentences. The sentences are taken from the Indonesian web corpus. The results of the data analysis in this study indicate that objects and complements are indeed different. From these differences clear and non-overlapping boundaries are obtained.
\end{abstract}

Keywords: definition, object, complement, literacy, lexicography 


\section{PENDAHULUAN}

Literasi baca tulis didefinisikan dalam Kamus Besar Bahasa Indonesia (KBBI) edisi V daring (tidak ada dalam KBBI V edisi cetak) sebagai 'kemampuan untuk memahami isi teks tertulis (tersirat maupun tersurat) dan menggunakannya untuk mengembangkan pengetahuan dan potensi diri, serta kemampuan untuk menuangkan ide atau gagasan ke dalam tulisan untuk berpartisipasi dalam lingkungan sosial'. Definisi tersebut menunjukkan bahwa literasi tidak dapat dipisahkan dari kemampuan berbahasa.

Kemampuan berbahasa yang paling dasar adalah kemampuan menyusun kalimat. Sasangka (2014, hlm. 19) menuliskan bahwa struktur kalimat dasar bahasa Indonesia dapat dikelompokkan ke dalam beberapa tipe berikut.

1. $\quad$ subjek-predikat (S-P)

2. subjek-predikat-objek (S-P-O)

3. subjek-predikat-pelengkap (S-P-Pel)

4. subjek-predikat-objek-pelengkap (S-P-O-Pel)

5. subjek-predikat-objek-keterangan (S-P-O-K)

6. subjek-predikat-keterangan (S-P-K)

Pengetahuan itu seyogianya dikuasai oleh penutur bahasa Indonesia sejak usia sekolah. Namun, dalam Kurikulum 2013 yang mengedepankan metode tematis, tata bahasa seperti di atas tidak lagi diajarkan di kelas. Padahal, ketidakpahaman pengguna bahasa terhadap kaidah bahasanya akan menghasilkan kesalahan berbahasa.

Pada saat memerlukan pengetahuan lebih lanjut mengenai fungsi unsur kata dan tidak mendapatkannya pada buku pelajaran, pemelajar atau penutur bahasa Indonesia biasanya akan mencari definisinya dalam kamus. Kamus merupakan buku yang pada intinya memuat informasi dari makna kata dan pemakaiannya dalam suatu situasi komunitas bahasa. Hal tersebut sejalan dengan poin-poin definisi kamus yang dipaparkan oleh Bejoint (2000, hlm. 18), yaitu kamus adalah tempat pengguna bahasa berkonsultasi untuk memperoleh atau memverifikasi informasi tertentu; kamus adalah sebuah buku didaktis; dan kamus memberikan informasi tentang tandatanda linguistik.

Sayangnya, sebagai kamus acuan yang digunakan secara luas oleh penutur bahasa Indonesia, definisi yang ada di KBBI terlihat tidak dimutakhirkan sesuai dengan perkembangan ilmu pengetahuan. Definisi objek dan pelengkap dalam KBBI tidak berubah semenjak edisi kedua. Definisi objek yang berhubungan dengan linguistik dalam KBBI mengalami perubahan dari edisi pertama ke edisi kedua. Dalam edisi pertama (1988, hlm. 622), objek yang berhubungan dengan linguistik didefinisikan sebagai 'pelengkap dl kalimat'. Dalam edisi kedua (1991, hlm. 698), definisi polisem ke-3 dari objek berubah menjadi ' 3 Ling nomina yg melengkapi verba transitif dl klausa, msl teh manis dl kalimat Kiki minum teh manis'. Definisi itu sama persis dengan definisi objek dalam Kamus Linguistik Kridalaksana (1982-2009), berikut kata turunan dan contohnya. Hingga KBBI edisi terakhir (2017, hlm. 1161), definisi objek itu tidak pernah berubah lagi. Sementara itu, dalam lema turunan dari pelengkap tercantum definisi pelengkap penderita adalah 'objek langsung' dan definisi pelengkap penyerta adalah 'objek taklangsung'. Dalam definisi tersebut terdapat pengacauan antara objek dan pelengkap, padahal objek bukan pelengkap dan pelengkap tidak sama dengan objek. 
Berkaitan dengan latar belakang dan masalah yang dipaparkan di atas, rumusan masalah dalam penelitian ini adalah sebagai berikut.

1. Apa saja fungsi objek dalam kalimat?

2. Apa saja fungsi pelengkap dalam kalimat?

3. Apa perbedaan dari keduanya?

4. Bagaimana objek dan pelengkap semestinya didefinisikan?

Tujuan dari penulisan makalah ini adalah untuk memberikan penjelasan mengenai pengertian objek dan pelengkap yang sesuai dengan ide yang dikandungnya berdasarkan teori fungsionalisme serta menyajikan usulan definisi yang tepat.

\section{TINJAUAN PUSATAKA DAN KERANGKA TEORI}

Sebelum membahas masalah objek dan pelengkap, perlu dikaji terlebih dahulu awal mula penyusunan tata bahasa bahasa Indonesia dan penjelasan para pakar bahasa Indonesia terdahulu. Berikut adalah ringkasannya.

Poedjawijatna dan Zoetmulder dalam bukunya Tatabahasa Indonesia untuk Sekolah Landjutan Atas (1955, hlm. 10) menjelaskan bahwa objek adalah bagian dari predikat dan bagi verba transitif objek biasanya melengkapi predikat-pokok. Penjelasan ini disertai dengan catatan kaki yang menyatakan objek sering juga disebut pelengkap penderita karena sifatnya "melengkapi". Objek disebut pelengkap penderita karena referen objek menderita sebagai akibat dari tindakan yang dinyatakan dalam predikat. Karena menjadi arah atau tujuan tindakan, objek disebut juga tujuan. Menurut Poedjawijatna dan Zoetmulder, istilah objek bersinonim dengan pelengkap penderita, pelengkap penyerta, dan tujuan.

Sutan Takdir Alisjahbana dalam Tatabahasa Baru Bahasa Indonesia (1983, hlm. 101) menyatakan bahwa pelengkap dan objek adalah hal yang sama dengan menyatakan "Keterangan predikat yang amat rapat hubungannya dengan predikat itu kita namakan pelengkap atau objek". Pelengkap adalah benda atau yang dibendakan. Alisjahbana membagi pelengkap dalam beberapa bagian, yaitu pelengkap penderita, pelengkap pelaku, dan pelengkap penyerta. Tiga bagian dari pelengkap inilah yang kemudian diambil menjadi sublema pelengkap dalam KBBI. Padahal, menurut Alisjahbana (1983, hlm. 101), pelengkap penderita, pelengkap pelaku, dan pelengkap penyerta adalah objek.

KBBI edisi kedua hingga kelima mengambil definisi objek beserta contoh-contohnya dari Kamus Linguistik karya Kridalaksana (1982). Definisi pelengkap penyerta dan pelengkap penderita dalam KBBI pun sama dengan definisi keduanya dalam Kamus Linguistik itu. Namun, ada beberapa keterangan mengenai pelengkap dan kata turunan lainnya yang tidak diambil oleh KBBI. Kata turunan dari pelengkap yang tidak diambil itu adalah pelengkap musabab, pelengkap objek, pelengkap pelaku, pelengkap pemeri, pelengkap pengkhususan, pelengkap resiprokal, dan pelengkap subjek. Definisi yang tidak diambil ini justru dapat memperjelas perbedaan antara objek dan pelengkap. Definisi pelengkap penderita dan pelengkap penyerta yang diambil oleh KBBI merupakan definisi yang perlu diuji lagi ketepatannya. Definisi pelengkap penyerta dan pelengkap penderita dalam KBBI kemungkinan diambil dari Sutan Takdir Alisjahbana (1983).

Dalam Tata Bahasa Baku Bahasa Indonesia (TBBI) edisi ke-4 (2017, hlm. 422) tertulis, "pengertian objek dan pelengkap sering dicampuradukkan. Hal itu dapat dipahami karena antara kedua konsep itu memang terdapat kemiripan." Untuk menghindari kesalahpahaman pengguna bahasa terhadap pengertian objek dan pelengkap itu, perlu dibuat batasan yang jelas yang dapat 
membedakan keduanya. Sayangnya, pernyataan tersebut tidak disertai dengan penjelasan yang lebih komprehensif mengenai pelengkap. Buku itu hanya menyajikan beberapa contoh kalimat berpelengkap beserta tabel perbedaan antara objek dan pelengkap (lihat Tabel 1).

\begin{tabular}{|c|c|}
\hline Objek & Pelengkap \\
\hline 1. berwujud frasa nominal atau klausa & $\begin{array}{l}\text { 1. berwujud frasa nominal, frasa verbal, frasa } \\
\text { adjektival, frasa preposisional, atau klausa }\end{array}$ \\
\hline $\begin{array}{l}\text { 2. berada langsung di sebelah kanan predikat } \\
\text { verba atau frasa verbal transitif }\end{array}$ & $\begin{array}{l}\text { 2. berada langsung di sebelah kanan predikat } \\
\text { verba atau frasa verbal taktransitif, berada di } \\
\text { belakang objek jika predikatnya berupa } \\
\text { verba transitif }\end{array}$ \\
\hline $\begin{array}{l}\text { 3. dapat menjadi subjek dalam pemasifan } \\
\text { kalimat }\end{array}$ & $\begin{array}{l}\text { 3. tidak dapat menjadi subjek dalam pemasifan } \\
\text { kalimat }\end{array}$ \\
\hline 4. dapat diganti dengan -nya & $\begin{array}{l}\text { 4. tidak dapat diganti dengan -nya, kecuali da- } \\
\text { lam kombinasi preposisi, selain } d i, k e \text {, dari, } \\
\text { dan akan }\end{array}$ \\
\hline
\end{tabular}

Tabel 1 Ciri Objek dan Pelengkap dari TBBI Edisi Keempat (2017, hlm. 423)

Dalam daftar istilahnya, TBBI mendefinisikan objek dan pelengkap sebagai berikut (2017, hlm. 584-585).

Objek 'fungsi sintaksis yang kehadirannya ditentukan oleh predikat yang berupa verba transitif pada kalimat aktif'

Pelengkap 'kata berwujud nomina atau frasa nominal dan juga dapat menduduki tempat yang sama, yakni di sebelah kanan verba predikat'

Definisi pelengkap tersebut agak membingungkan dan agak sedikit menyimpang dari daftar ciri pelengkap yang ditampilkan dalam Tabel 1 .

Penelitian mengenai objek dan pelengkap dalam bahasa Indonesia dewasa ini tidak banyak. Dari penelitian yang hanya sedikit itu, terdapat perbedaan dalam penamaan istilah. Suhandano (2002) menganggap ada konstruksi objek ganda. Salah satu contoh yang diberikan oleh Suhandono adalah klausa Tuti mengambilkan Wati air minum. Menurutnya, Wati dan air minum adalah objek. Sementara itu, Kesuma (2010, hlm. 73) menyatakan bahwa tidak ada pengertian objek ganda. Ia hanya mengakui satu jenis fungsi objek. Namun, menurutnya tidak semua verba transitif memerlukan objek. Dalam beberapa kasus, objek dari verba transitif dapat lesap. Penelitian Kesuma (2010) didasarkan pada data yang didapat dari penggunaan bahasa.

Penelitian ini menggunakan teori sintaksis fungsional (Kridalaksana, 2003). Melalui teori dalam fungsionalisme dapat diperjelas fungsi objek dan pelengkap dalam bahasa Indonesia. Apa yang selama ini disebut sebagai objek tidak langsung atau pelengkap penyerta merupakan pandangan yang tidak tepat jika ditilik dari sudut semantis. Dalam teori ini analisis sintaktis dan analisis semantis merupakan dua tataran analisis yang berbeda. Analisis sintaktis menganalisis struktur bahasa sehingga diperoleh fungsi subjek, predikat, objek, pelengkap, dan keterangan. Sementara itu, dalam analisis semantis, kalimat dipandang sebagai sebuah proposisi yang merupakan konfigurasi makna yang menjelaskan isi komunikasi dari pembicara yang terjadi dari predikator yang berkaitan dengan satu argumen atau lebih (Kridalaksana, 2002), seperti yang terlihat dalam Bagan 1 berikut. 


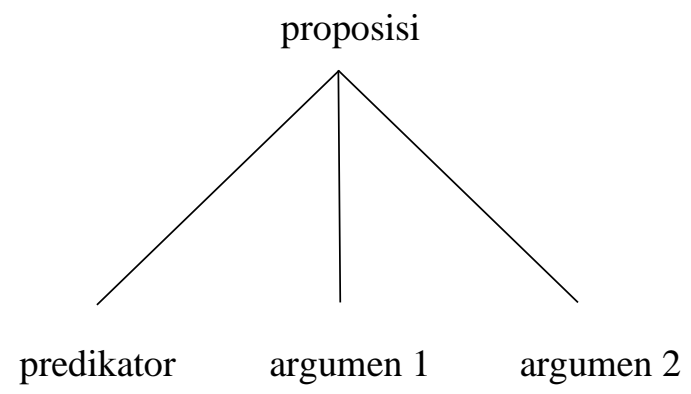

Bagan 1. Bagan Proposisi

Teori leksikografi yang dijadikan acuan adalah teori pendefinisian lema kamus ekabahasa yang dikemukakan oleh Atkins dan Rundell (2008). Dalam teori ini dijelaskan faktor-faktor apa yang harus diperhatikan dalam pendefinisian suatu kata.

\section{METODE PENELITIAN}

Metode yang digunakan dalam penelitian ini adalah metode deskriptif kualitatif melalui studi dokumen. Dokumen yang digunakan adalah Kamus Besar Bahasa Indonesia dari edisi pertama hingga edisi terbaru, kamus-kamus linguistik, baik bahasa Indonesia maupun bahasa Inggris, buku Tata Bahasa Baku Bahasa Indonesia edisi ketiga dan keempat, serta buku-buku teori yang khusus membahas masalah tata bahasa, khususnya mengenai objek dan pelengkap. Definisi dari kamus-kamus tersebut dibandingkan dengan pendapat dan hasil penelitian pakar bahasa Indonesia, kemudian berdasarkan teori sintaksis fungsional, definisi objek dan pelengkap dalam bahasa Indonesia itu diulas kembali.

Untuk memperjelas fungsi objek dan pelengkap yang sesuai dengan perkembangan bahasa dan ilmu pengetahuan, diperlukan data berupa kalimat yang autentik. Kalimat yang disusun oleh penutur bahasa Indonesia secara langsung dan natural, bukan kalimat buatan peneliti. Oleh karena itu, data diambil dari korpus web. Korpus yang dimaksud adalah kumpulan artikel berita berbahasa Indonesia yang terhimpun dalam mesin pencari google. Model korpus semacam ini dinamakan web as corpus (Gatto, 2014). Dari korpus tersebut, diambil enam kalimat tuturan natural untuk menjadi sampel data penelitian, yaitu

(1) Saya menghindari makan nasi.

Sumber: https://bangka.tribunnews.com > Dec 21, 2017

"Saya menghindari makan nasi karena kalau saya makan nasi, saya kenyang dengan cepat. Itu tidak menyenangkan," kata Dewi Hughes.

(2) Semua orang suka menyanyi.

Sumber: friskajuronline.blogspot.com/.../apakah-anda-suka-bernyanyi.html, Des 1, 2011

Kesimpulannya hampir semua orang suka menyanyi. Karena menyanyi dan memainkan alat musik merupakan suatu seni yang menyenangkan.

(3) Seorang anak menulis surat untuk ayahnya.

Sumber: https://id.theasianparent.com > Kisah Mengharukan

Iklan Metlife Hong Kong berdurasi 3 menit ini sangat mengharukan. Seorang anak menulis surat untuk ayah. Ayah adalah yang terbaik baginya, tetapi ia ... 
(4) Fransisca menculik anak kandungnya sendiri.

Sumber: https://news.detik.com/.../pasal-ibu-menculik-anak-kandung-dinilai..., Des 21, 2011

Hal ini didasari atas tuduhan polisi dan jaksa jika Fransisca menculik anak kandungnya sendiri, Jason (11) yang kini menjalani proses sidang ...

(5) Seorang wanita mencarikan suaminya istri kedua.

Sumber: https://www.liputan6.com > Citizen6, Jul 29, 2019

Artikel tentang ketulusan seorang wanita mencarikan suaminya istri kedua menjadi yang terpopuler di kanal Citizen6, Liputan6.com.

(6) Destry Damayanti resmi menjadi Deputi Gubernur Senior Bank Indonesia (BI).

Sumber: https://nasional.kontan.co.id/.../destry-damayanti-resmi-menjadi-de..., Jul 11, 2019

Destry Damayanti resmi menjadi Deputi Gubernur Senior Bank Indonesia (BI) secara aklamasi.

Data-data tersebut dianalisis menggunakan pendekatan fungsionalisme dengan menganalisis fungsi sintaktis dan semantisnya. Hasil yang diperoleh diformulasikan dengan mengindahkan prinsip-prinsip leksikografi agar diperoleh definisi yang tepat dan sesuai untuk kamus umum.

\section{PEMBAHASAN}

Analisis mengenai objek dan pelengkap dilakukan melalui pemeriksaan beberapa contoh kalimat autentik yang diujarkan pengguna bahasa. Analisis dimulai dengan memeriksa definisi objek 'nomina yang melengkapi verba transitif dalam klausa'. Untuk mengetahui apakah objek selalu berupa nomina, analisis dilakukan pada kalimat (1) dan (2).

(1) Saya menghindari makan nasi.

(2) Semua orang suka menyanyi.

Menghindari adalah verba transitif yang memerlukan objek. Hal yang dihindari harus muncul untuk menjelaskan apa yang dihindari. Kata suka, walaupun dalam beberapa kasus dapat digunakan tanpa objek, dalam kalimat (2) memerlukan objek untuk menjelaskan apa yang disukai subjek. Makan nasi berfungsi untuk menjelaskan apa yang dihindari oleh saya dan menyanyi berfungsi untuk menjelaskan apa yang disukai oleh semua orang. Namun, kelas kata dari objek di contoh (1) dan (2) itu adalah frasa verbal dan verba, bukan nomina.

Langkah selanjutnya adalah mengecek ketepatan fungsi dari unsur kalimat-kalimat di atas melalui analisis semantis dengan menggunakan proposisi. Dari proposisi akan terlihat konfigurasi makna apa saja yang dapat terjadi dari hubungan predikator dengan argumen-argumen setiap kalimat tersebut. 


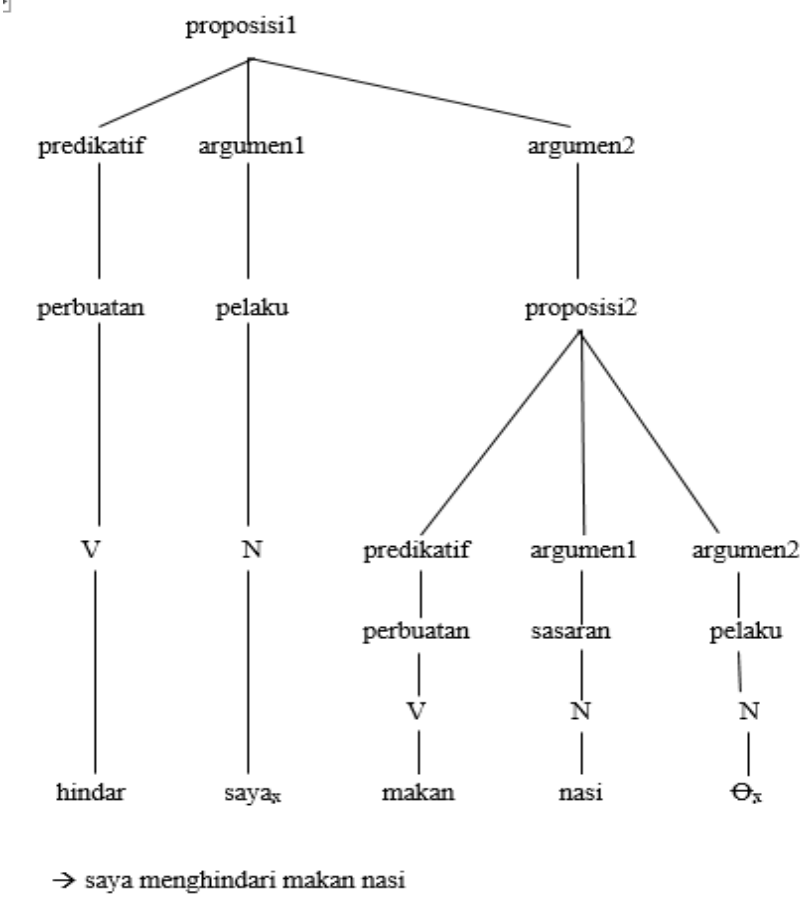

Gambar 1. Bagan Proposisi Kalimat (1)

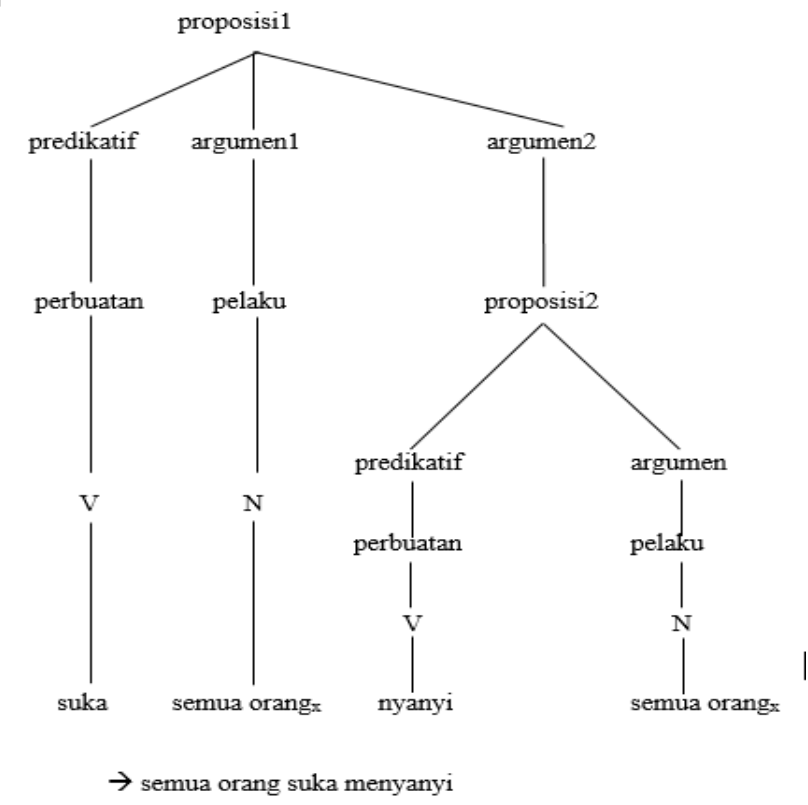

Gambar 2. Bagan Proposisi Kalimat (2)

Makan nasi dan menyanyi merupakan objek karena posisinya dapat disubstitusikan oleh kata lain yang berupa nomina atau frasa nominal seperti dalam kalimat-kalimat berikut.

\section{Saya menghindari macet.}

pelaku perbuatan sasaran

$\mathrm{N}$ 


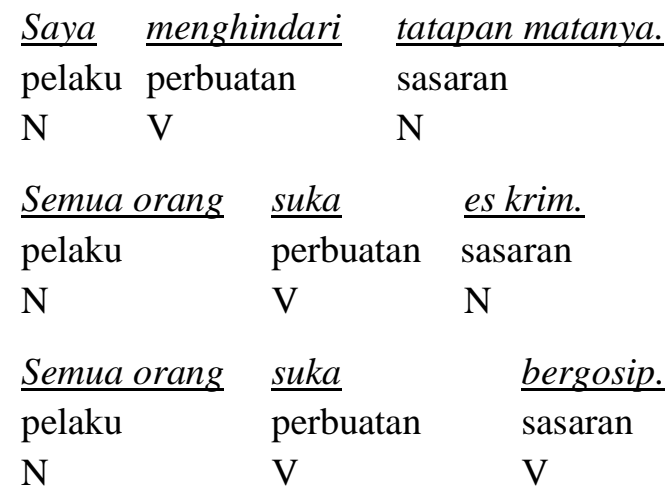

Hal ini menunjukkan bahwa objek bukan hanya berupa nomina, tetapi juga dapat berupa frasa verbal, verba, dan adjektiva.

Dalam kalimat (1), makan nasi merupakan sasaran dari perbuatan menghindar yang dilakukan oleh saya, tetapi bukan hasil dari perbuatan menghindar. Dalam kalimat (2), menyanyi juga bukan merupakan hasil dari perbuatan suka. Objek yang dikenai oleh perbuatan yang terdapat dalam predikat verbal, tetapi tidak merupakan hasil dari perbuatan itu disebut objek yang bersifat afektif (Kridalaksana, 2002).

Analisis kalimat (3) dan (4) berikut ini dilakukan untuk membuktikan apakah objek berfungsi untuk melengkapi predikat verbal.

(3) Seorang anak menulis surat untuk ayahnya.

Menulis dalam kalimat [3] adalah verba transitif yang memerlukan objek. Dalam kalimat itu objeknya adalah surat. Tanpa objek, kalimat itu dapat menimbulkan pertanyaan karena tidak jelas apa yang ditulis. Walaupun konteks kalimat dapat diketahui melalui kalimat-kalimat sebelumnya, penghilangan objek tetap dapat menimbulkan kebingungan bahkan kesalahpahaman. Untuk menghindari hal itu, sebaiknya objek tidak didefinisikan sebagai nomina yang melengkapi verba transitif, tetapi sebagai sesuatu yang selalu hadir setelah verba transitif.

Analisis proposisi dari kalimat (3) menunjukkan bahwa surat dalam kalimat di atas merupakan hasil dari perbuatan menulis seorang anak yang ia lakukan untuk ayahnya. Objek yang merupakan hasil perbuatan yang terdapat dalam predikat verbal disebut objek efektif (Kridalaksana, 2002).

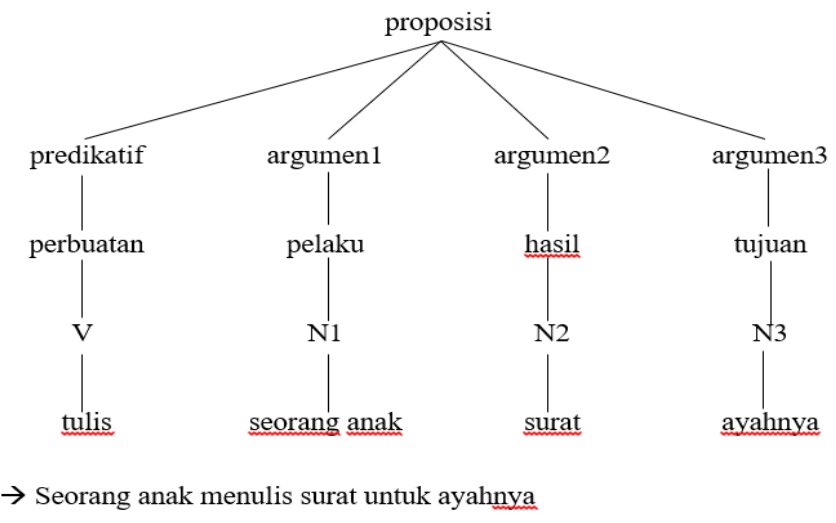

Gambar 3. Bagan Proposisi Kalimat (3) 
(4) Fransisca menculik anak kandungnya sendiri.

Predikat dalam kalimat (4) juga merupakan verba transitif yang memerlukan objek, yaitu anak kandungnya sendiri. Berdasarkan fungsi sintaksisnya, struktur kalimat (4) adalah S-P-O. Tanpa objek, kalimat (4) menjadi tidak jelas. Pada saat membaca kata menculik, orang akan mengharapkan informasi selanjutnya, yaitu objek yang merupakan sasaran dari perbuatan menculik itu.

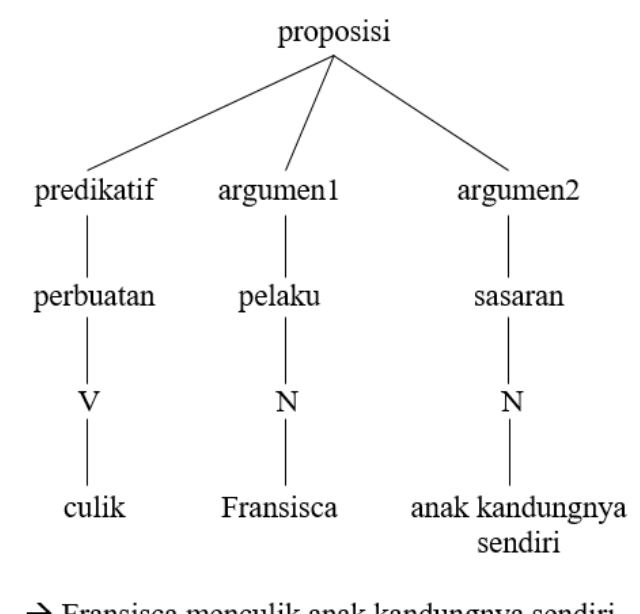

Gambar 4. Bagan Proposisi Kalimat (4)

Sebagai sasaran yang dikenai akibat dari perbuatan menculik, anak kandungnya sendiri dalam tataran sintaktis merupakan objek afektif.

Selanjutnya, penjelasan mengenai pelengkap dan beberapa jenis pelengkap dapat dilihat dari analisis kasus dalam contoh kalimat (5) dan (6) di bawah ini.

(5) Seorang wanita mencarikan suaminya istri kedua.

Kata mencarikan dalam kalimat (5) merupakan verba transitif yang disertai pelengkap dan objek yang berupa nomina dan frasa nominal. KBBI dan Kamus Linguistik (2008) menyebutkan bahwa objek yang mendapatkan keuntungan dari perbuatan yang terkandung dalam verba dinamakan objek tidak langsung atau disebut juga sebagai pelengkap penyerta. Padahal, dari sudut semantis penjelasan itu kurang tepat. Untuk mengetahui fungsi dari tiap-tiap unsur dengan lebih jelas, kita lihat analisis semantis berikut. 


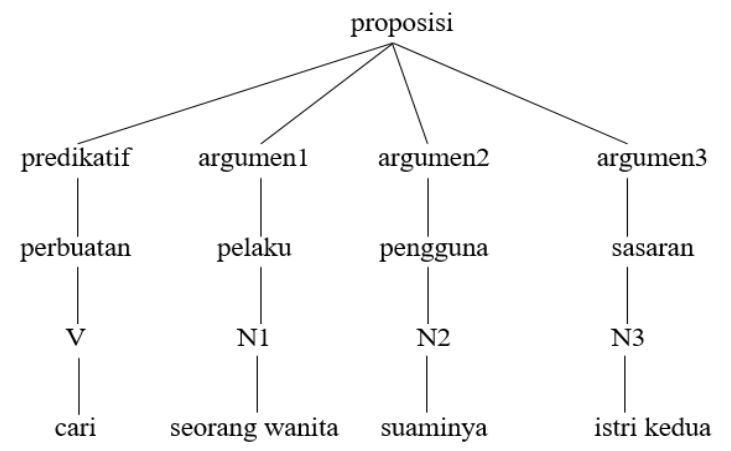

$\rightarrow$ Seorang wanita mencarikan suaminya istri kedua

$\rightarrow$ Seorang wanita mencarikan istri kedua untuk suaminya

Gambar 5. Bagan Proposisi Kalimat (5)

Suaminya adalah orang yang mendapatkan keuntungan dari perbuatan mencarikan yang dilakukan oleh seorang wanita. Nomina atau frasa nominal yang secara semantis mendapatkan keuntungan dari perbuatan yang terkandung dalam verba disebut pelengkap pengguna (Kridalaksana, 2002). Sementara itu, istri kedua adalah sasaran dari perbuatan mencarikan yang dilakukan untuk suaminya. Fungsi dari frasa istri kedua dalam kalimat (5) adalah sebagai objek.

Selain melengkapi verba transitif, pelengkap juga diperlukan keberadaannya untuk melengkapi verba intransitif yang berfungsi sebagai predikat. Verba menjadi pada kalimat (6) merupakan contoh verba intransitif yang diikuti pelengkap.

(6) Destry Damayanti resmi menjadi Deputi Gubernur Senior Bank Indonesia (BI).

Pelengkap dapat berupa nomina, adjektiva, frasa nominal, frasa verbal, frasa adjektival, frasa preposisional, atau klausa. Pelengkap dalam kalimat (6) adalah Deputi Gubernur Senior Bank Indonesia (BI). Secara semantis, pelengkap ini merujuk kepada subjek sehingga dinamakan pelengkap subjek (Kridalaksana, 2008). Bagan proposisi untuk kalimat (6) adalah sebagai berikut.

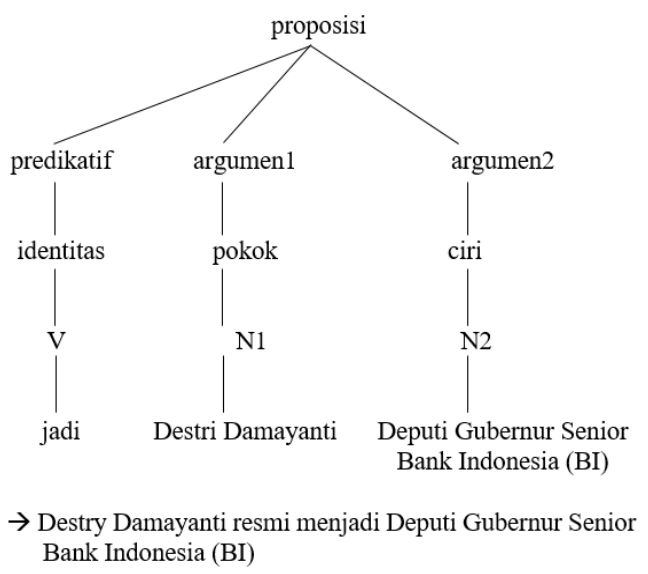

Gambar 6. Bagan Proposisi Kalimat (6)

Peran Destri Damayanti dalam kalimat (6) adalah sebagai pokok dari identitas menjadi ciri Deputi Gubernur Senior Bank Indonesia (BI). 
Jenis-jenis pelengkap dapat diamati dari tataran semantis. Pelengkap pengguna dan pelengkap subjek merupakan bagian dari jenis-jenis pelengkap. Masih ada beberapa jenis pelengkap lain yang karena keterbatasan ruang tidak dapat dibahas seluruhnya dalam makalah ini.

Dari analisis data yang terbatas di atas didapat beberapa poin yang dapat digunakan untuk bahan perbaikan definisi KBBI. Poin-poin tersebut adalah sebagai berikut.

1. Objek bukan hanya berupa nomina atau frasa nominal, tetapi juga bisa verba, frasa verbal atau adjektiva.

2. Objek tidak berfungsi untuk melengkapi. Kehadirannya menyertai predikat yang berupa verba transitif dalam kalimat aktif merupakan keharusan.

3. Objek terbagi menjadi objek afektif dan objek efektif.

4. Fungsi pelengkap lebih luas daripada objek. Selain melengkapi verba intransitif dalam kalimat aktif dan melengkapi kalimat pasif, pelengkap juga dapat hadir pada kalimat transitif.

5. Pelengkap dapat berupa verba, frasa verbal, atau adjektiva.

6. Dalam tataran semantis, pelengkap dapat berupa ciri, pengguna, pelaku, dan penanggap.

7. Pelengkap pengguna adalah objek afektif atau efektif dalam tataran sintaktis atau sasaran dalam tataran semantis.

8. Pelengkap penyerta sesungguhnya adalah pelengkap pengguna dalam tataran sintaktis atau pengguna dalam tataran semantis.

9. Superordinat dari subjek, predikat, objek, pelengkap, dan keterangan adalah fungsi sintaktis.

Poin-poin di atas masih perlu dikuatkan dengan pembuktian lebih lanjut dengan data yang lebih besar. Namun, poin-poin di atas sudah dapat dijadikan bahan pertimbangan untuk usul perbaikan definisi yang diramu dengan mengacu pada prinsip leksikografi. Usul perbaikan yang ditawarkan adalah sebagai berikut.

Objek 'fungsi sintaktis dalam klausa atau kalimat aktif berupa nomina, frasa nominal, verba, frasa verbal, atau adjektiva yang selalu menyertai predikat berkelas verba transitif'

Pelengkap 'fungsi sintaktis dalam klausa atau kalimat berupa kata atau frasa yang melengkapi predikat berkelas verba transitif dan intransitif'

Kata melengkapi tidak lagi digunakan dalam pendefinisian objek untuk menghindari kerancuan dengan pelengkap. Dalam definisi pelengkap tidak disebutkan jenis kata atau frasanya secara mendetail karena semua jenis kata dan frasa dapat menjadi pelengkap.

Pencantuman kata turunan dari objek dalam KBBI perlu ditinjau ulang karena ada istilah seperti objek tak langsung, istilah bersinonim seperti objek primer, objek sekunder, dan objek faktitif yang perlu dikaji lebih lanjut ketepatan definisinya. Dengan demikian, secara otomatis kata turunan dari pelengkap beserta definisinya dalam KBBI juga perlu dikaji ulang, diperbaiki, dan disesuaikan dengan kebutuhan mayoritas pengguna kamus.

\section{SIMPULAN}

Literasi baca tulis harus ditunjang oleh alat bantu yang dapat meningkatkan kualitas. Salah satu alat bantu itu adalah kamus. Untuk tujuan itu, kamus harus berisi informasi yang tepat dan tidak membingungkan penggunanya. Definisi kamus harus didasarkan pada hasil kajian yang diformulasikan dalam susunan kalimat yang mudah dipahami. 
Sebagai salah satu fungsi unsur dalam kalimat, objek dan pelengkap dalam KBBI didefinisikan bertumpang-tindih. Tata bahasa tradisional menyebutkan bahwa objek dan pelengkap adalah fungsi unsur yang sama. Penelitian ini telah membuktikan bahwa sejalan dengan perkembangan bahasa Indonesia dan teori linguistik, terdapat perbedaan antara objek dan pelengkap. Oleh karena itu, batasannya harus dibuat jelas dan tidak tumpang-tindih.

Dewasa ini kajian tentang unsur kalimat dalam bahasa Indonesia semakin berkurang. Hal ini terlihat dari sulitnya mendapatkan referensi terbaru. Banyak yang menganggap penelitian di bidang ini sudah selesai, tidak ada celah lagi untuk dikaji. Hasilnya, definisi unsur kalimat dalam KBBI pun tidak berubah sejak beberapa edisi. Penelitian ini menunjukkan bahwa masih ada hal yang dapat dikaji dari unsur kalimat. Bahasa dan ilmu pengetahuan yang terus berkembang menjadikan tata bahasa juga perlu terus-menerus dikembangkan.

Penelitian ini merupakan penelitian awal untuk memutakhirkan definisi kosakata yang berhubungan dengan tata bahasa bahasa Indonesia sesuai dengan perkembangan bahasa Indonesia. Masih banyak penelitian yang dapat dilakukan untuk mengkaji apakah fungsi unsur kalimat lainnya, seperti subjek dan predikat, sudah sesuai dengan yang didefinisikan. Penelitian lebih mendalam tidak hanya akan menjadi usul perbaikan definisi KBBI, tetapi dapat juga menjadi usul perbaikan Tata Bahasa Baku Bahasa Indonesia.

\section{CATATAN}

Penulis berterima kasih kepada mitra bebestari yang telah memberikan masukan yang berharga untuk meningkatkan kualitas makalah ini.

\section{DAFTAR PUSTAKA}

Alisjahbana, S. T. (1983). Tatabahasa baru bahasa Indonesia: Jilid 1 (cetakan ke-44, ditambah dan diubah). Jakarta: Penerbit Dian Rakyat.

Alwi, H., Dardjowidjojo, S., Lapoliwa, H. \& Moeliono, A.M. (2000). Tata bahasa baku bahasa Indonesia (edisi ketiga). Jakarta: Balai Pustaka.

Bejoint, H. (2000). Modern lexicography: An introduction. Oxford: Oxford University Press.

Gatto, M. (2014). Web as corpus: Theory and practice. London: Bloomsbury Academic.

Kesuma, T.M.J. (2010). Verba transitif dan objek dapat lesap dalam bahasa Indonesia. Linguistik Indonesia 28(1), 68-75.

Kridalaksana, H. (2002). Struktur, kategori, dan fungsi dalam teori sintaksis. Jakarta: Universitas Katolik Indonesia Atma Jaya.

Kridalaksana, H. (2008). Kamus linguistik (edisi keempat). Jakarta: Gramedia Pustaka Utama.

Poedjawijatna, I.R. \& Zoetmulder, P.J. (1955). Tatabahasa Indonesia untuk sekolah landjutan atas jilid II: Bentuk kalimat. Jakarta: N.V. Obor.

Sasangka, S.S.T.W. (2016). Seri penyuluhan bahasa Indonesia: Kalimat. Jakarta: Pusat Pembinaan, Badan Pengembangan dan Pembinaan Bahasa, Kementerian Pendidikan dan Kebudayaan.

Sue Atknis, B.T. \& Rundell, M. (2008). The Oxford guide to practical lexicography. Oxford: Oxford University Press. 
Suhandano (2002). Konstruksi objek ganda dalam bahasa Indonesia. Humaniora XIV(1/2002), $70-76$.

Tim Penyusun. (1988). Kamus besar bahasa Indonesia. Jakarta: Departemen Pendidikan dan Kebudayaan Republik Indonesia.

Tim Penyusun. (2017). Kamus besar bahasa Indonesia (edisi kelima). Jakarta: Badan Pengembangan dan Pembinaan Bahasa, Kementerian Pendidikan dan Kebudayaan.

Tim Penyusun. (2017). Tata bahasa baku bahasa Indonesia (edisi keempat). Jakarta: Badan Pengembangan dan Pembinaan Bahasa, Kementerian Pendidikan dan Kebudayaan. 